\title{
Adult Education Programmes for Poverty Reduction among People with Special Needs
}

\author{
Adedokun Mary Olufunke \\ Faculty of Education, Ekiti State University \\ E-mail: funkadokun@yahoo.com, Tel: 1234-8034-80-6200
}

\section{Doi:10.5901/jesr.2013.v4n3p317}

\section{Abstract}

\begin{abstract}
This paper examined what role adult education programmes could play in addressing the issue of poverty among people with special needs. The paper looked at adult education as a field of study that incorporates everybody in the society the poor, rich, people with special needs and those without, the young and old are all catered for by various adult education programmes with the intention of reducing poverty to the barest minimum among not only the people with special needs but among every community member. Adult education in this paper is thus seen as a tool for empowerment that will free people from their poverty ridden situation. Irrespective of the needs of people with special needs they must be loved, accommodated and catered for within the enclave of the society in which they live. They are not to be sympathized but be empowered and this can be done through the various programmes of adult education. The paper suggests that poverty can be minimized among people with special needs through distribution of resources and power. It also concludes that poverty reduction strategies must be embarked upon for the almost neglected people with special needs and opportunities should be made available to such people through floating various programmes of adult education which emphasize the values of democracy where everybody works side by side in order to create a dynamic and caring community for people of all ages and varied abilities.
\end{abstract}

Keywords: poverty ridden situation,inclusiveness, functionality, disability and democracy

\section{Introduction}

This paper examined the roles of various adult education programmes in poverty reduction among people with special needs. There is this tendency to look down on people with special needs as people with a disadvantaged background or look at them as people with marital, emotional or even physical disability and who will not be able to do any useful thing hence, they are usually poverty ridden and which should not be so bearing in mind that both able bodied people and those with special needs have got potentials for great achievements. It is on this basis that many adult education programmes become useful for these people since adult education is that education that preaches inclusiveness and one in which everybody can find him/herself useful

\section{Adult Education}

When mention is made of adult education, the general opinion of people is one that deals with education of the adult who has never been to school before and just intends learning to read $a, b, c$ and learning to write $1,2,3$. No matter what the opinions of people are about adult education, it remains a useful type of education, one that reflects people's values and also adds positive functionality to people's lives (Aitchison and Alidou, 2009). Adult education is rooted in lifelong learning which involves the pursuit of knowledge either for personal or professional reasons (Department of Education and Science, 2000). The aim of adult education is to involve everyone in life-long learning as it not only enhances social inclusion, active citizenship and personal development but also competitiveness and employability. The implication of this is that adult education is for all; whether having special needs or not. It also implies that learning is not confirmed to childhood, classroom or persons without special needs but to everyone (Gerhard, 2000).

In adult education, learning can be seen as something that takes place in an ongoing basis from our daily interactions with the world around us. Adult education becomes a useful tool in freeing people from poverty ridden situations when one under- stands the role of adult education in empowering individuals to become self-sufficient and self reliant with skills necessary for future or present employment and personal successes (USOE, 2013). When adult education is viewed as a tool for empowerment and subsequently a tool for raising one's living standard, it will thus lead to poverty reduction not only in persons without special needs but also in people with special needs and this is why adult 
education is an inclusive one, its programmes do not favour one group at the expense of the other. It can thus be said of adult education that its programmes include all activities with educational purposes, carried on by people in the ordinary business of life that use only part of their energy to acquire intellectual equipment (Maulau, 2013).

\section{Programmes of Adult Education}

Adult education activities are very wide in scope especially when it is viewed as forming part of lifelong education and learning. They have no theoretical boundaries as the programmes meet the specific needs of individuals and groups in any society and people with special needs inclusive. The activities cover different aspects of life to the extent that they have potency for poverty reduction even among the underrated people with special needs. Adult education is so wide in scope that it involves everybody and all our activities.

Nyerere (1979) sees adult education as things which are not only concerned with agriculture our health or literacy or medical skill but something more than these. He saw all these as separate branches of adult education that are related to the total life a man is living. This is to say that adult education embraces the entire life and so Nzeneri (2002) sees it as education for life and because life activities are broad and complex, then education for life will be broad and complex to the extent that it will mean no exclusion of any group of people and it will also help in poverty alleviation. Some of the programmes of adult education that will help in poverty alleviation include:

(a) Remedial (Adult Education Programme): this programme is used for remediating the deficiencies which people both able bodied and those with special needs experience through the non-acquisition of certain levels of formal schooling. When certain level of education is attained, then poverty can be shaken off with good employment.

(b) Vocational and Technical Programme of Adult Education: This is concerned with getting skills in preparation for self-reliant work. Virtually everybody including people with special needs can be prepared for useful living through this programme of adult education.

(c) Health, Welfare and Family life: This implies education about physical and mental health. When people are in good state of health, they are able to work and earn a living thereby, having a better living standard.

(d) Civil, Political and Community Education: This will give instructions about national and international matters. The fact that some people have special needs should not relegate them to the background in national and international issues. When their ears are opened to political events, they are better informed and so able to fight for their rights.

(e) Another form of adult education is self-fulfillment and liberal adult education programmes. These are programmes of adult education undertaken for the enjoyment of the individual. The list of the programmes of adult education that can rid one of poverty is in exhaustive and all these programmes can come under formal adult education, non-formal adult education and informal adult education.

The implication of the above is that adult education is inclusive and so everybody especially people with special needs should be encouraged to take part so as not to be left out in the scheme of things.

\section{People with Special Needs and Poverty}

There are people with special needs all around us but what are our attitudes towards them and what efforts are we all making to ensure that they live well in our communities? This is a task that must not be left to the government alone. Everyone must be involved in sharing life and work with these people with special needs.

There are various ways by which people with special needs are referred to. Some refer to them as the disabled, some of them as the challenged while they are also referred to as people with special needs. Whatever way they are referred to, the fact remains that they are people like other able bodied persons who need to be loved and cared for in our communities. These people sometimes are seen as people with a disadvantaged background or people with mental, emotional or physical disability. They are people who need special help or care, so as to overcome poverty and disadvantage in various forms. People with special needs suffer from various disabilities which may be physical, sensory, visual, hearing, and developmental or people suffering from mental disorders. Disabilities can then be seen as an umbrella term, covering impairment, activity limitations and participation restrictions. Impairment in this situation is seen as a problem in body function or structure; an activity limitation is a difficulty encountered by an individual in executing a task or action while a participation restriction is a problem experienced by an individual in involvement in life. Disability therefore is a complex phenomenon, reflecting an interaction between features of a person's body and features of the 
society in which he or she lives (World Bank 2012). Whatever, the type of disability a person is suffering from, the community must accommodate and provide for the needs of such within a given community.

There has been a global correlation between disability and poverty. Disability and poverty may form a vicious circle in which physical barriers make it more difficult to get income, which in turn diminishes access to health care and other necessities for a healthy life (Yeo, 2005). Poverty is entrenched in people with disability as a result of discrimination in employment. The US Rehabilitation Act of 1973 recognizes this when it makes provision for all organizations that receive government funding to provide accessibility programmes and services for people with special needs. Not only this, in 1990, there was the law "Americans with Disabilities Act of 1990" (ADA) which became effective in 1992 prohibiting private employers, states and local governments, employment agencies and labour unions from discriminating against qualified individuals with disabilities in job application procedures; living, firing, advancement, compensation, job training or in terms of conditions and privileges of employment (http://en.wikipedia.org/woki/disability). This implies meting out equal treatment to everybody and doing this makes people with special needs for lively and alive to their responsibilities. People with special needs should not be seen with pity but as being able to do what others are capable of doing.

Over one million people, or approximately 15 percent of the world's population, live with some form of disability. Persons with disabilities often face barriers to participation in all aspects of society. Persons with disabilities do not have equal access to society or services including education, employment, health care, transportation, political participation or justice. When barriers to their inclusion are removed and they are empowered to participate fully in societal life, then poverty is reduced in their living conditions.

On the surface, poverty is defined as a lack of income or assets and so in the daily lives of the very poor, poverty becomes a network of disadvantages, each one exacerbating the other. Hence generations after generation of these poor lack access to education, healthcare, adequate housing, proper sanitation and good nutrition. Because they are poor, they are the most vulnerable to disasters, armed conflicts and systems of political and economic oppressions and moreover they are powerless to improve their circumstances (The Effects of Poverty 13-1-13). These poor conditions often carry with them dysfunctional family, bringing with it low self esteem, and even spiritual darkness. In essence poverty is associated with lack of hope.

Disability also brings along with it unequal social status and inequitable social relationships experienced as a social exclusion, and diminished capacity to participate or to develop meaningful connections with other people in society (The poor: social problem http://en.wikipedia.org/wiki/poverty).

These people with special needs experience absolute poverty or destitution which involves deprivation of basic human needs within the community such as food, water, sanitation, clothing, shelter, healthcare and education. They also suffer from economic inequality in the location or society in which they live (Poverty/Sociology -12-1-13).

Socially, people with special needs suffer also in the area of access to information, education, health care and political power. (A Glossary for Social Epidemiology, 12-1-13). With exposure to various adult education programmes,they will become informed and seek the best for their lives. Literacy programme will make the illiterates among people with special needs to become literate and have access to needed information, good health services and have access to the needed education to help them participate in political activities because knowledge is power. With access to education, poverty ravaging their life is on the way to being eradicated (World Bank 2007).

\section{Roles of Adult Education Programmes in poverty Education among People with Special Needs:}

It is a habit of almost everybody in our communities to either look down on people with special needs, as people who cannot measure up to the standard of those with special needs or to pity these people by just giving them stipends which in no way do not solve their problems. It is therefore, important to note that handouts of traditional aids are not enough to end poverty and its many entanglements among people with special needs. The most important way is to equip people with special needs to free themselves from poverty in a holistic way and this can be achieved through the already listed various programmes of adult education.

Government, organizations and individuals should come to the aid of people with special needs by exposing them to programmes of adult education be it formal, informal or non-formal adult education programmes and sponsoring them to partake in such so as to move people above poverty level as it has been discovered that extreme poverty is a global challenge (The World Bank, 2011).

The economic aspects of poverty focus on material needs including the necessities of daily living such as food and other necessities, poverty in this sense can be seen as a condition in which people in a given community are lacking in the basic needs for a minimum standards of well being and life particularly as a result of a persistent lack of income. In 
this situation, exposing people to the vocational, technical or other programmes of adult education would bring about solution as people can find something to do to generate incomes so as to raise their standard of living.

Poverty among people with special needs can be minimized through the provision of relational conditions. With community education, able bodied people will relate with the ones with special needs, understand their needs and provide for them specially.

Analysis of social aspects of poverty links conditions of scarcity to aspects of the distribution of resources and power in a society and recognizes that power may be a function of the diminished capacity of people to live the kinds of lives they value. People must therefore be empowered through mass education, literacy programmes - make them literate to access useful information that will free them from poverty and thus making them live a good life.

Persons with disabilities were shown by the World Bank to comprise 15-20 percent of the poorest individuals in developing countries (Elwan, 1999). Former World Bank President, James Wolfensohn, stated that this connection reveals a link that should be broken stating that people with disabilities in developing countries are over - represented among the poorest people. They have been largely overlooked with the development agenda so far but recent focus on poverty reduction strategies is a unique way to re-think and re-write that agenda (The World Bank 2011). Whatever the agenda is, whatever the way it is to be re-written, strategies to reduce poverty among people with special needs must include programmes of adult education as such programmes are non discriminatory and are also very inclusive.

Also, the United Kingdom Department for International Development reported that 10,000 individuals with disabilities die each day as a result of extreme poverty $(Y e 0,2005)$. The report says that the above shows that the connection between poverty and disability is especially problematic. Adult education programmes must not be neglected in bringing solutions to the problem of poverty in the lives of people with special needs.

In developed countries the Disability Funders Network reported that in the United States those with disabilities are twice more likely to live below the poverty line than those without special needs (Dickson, 2011),knowing this, programmes that will benefit people with special needs must be planned for them to make them live above poverty level .

\section{Conclusion}

Poverty reduction strategies must be embarked upon especially for the almost neglected people with disabilities and this fact is noted by various organizations such as the United Nations and the World Bank and thus such bodies have made poverty reduction a major goal because they recognize poverty to be a global challenge in spite of the efforts made to reduce instances of poverty (The world Bank, 2012). It is therefore important to build opportunities for self sufficiency for people with special needs and making employment opportunities available. The opportunities are available in adult education. When trained in diverse ways, there will be an increase in the income of people with special needs and this will afford them the opportunity of having access to basic needs of life thereby raising their living standard.

Businesses should be designed with a social goal in mind. People with special needs should also have access to financial institutions such as microfinance banks from where they can take loans to run small businesses.

Adult education programmes emphasise the values of democracy where everybody work side by side in order to create a dynamic and caring community of people of all ages and varied abilities. Adult education programmes recognize individual gifts in able bodied persons and those with special needs as well as those with societal and personal vulnerabilities. Through progammes of adult education, people with special needs will discover and develop their full potentials, and use them to better their lot so that poverty will release its hold on them. No matter what the disability being suffered that has led to poverty, with various programmes of adult education, people with special needs can live above poverty level and so all hands must be on deck to see that people with special needs are helped, cared for and made to have better income so as to contribute not only to their personal development but also to national development.

\section{References}

"A Glossary for Social Epidemiology" - World Health Organisation. March 2002. Retrieved 2011-06-21 (Accessed 12-1-13).

"Disabilities": World Health Organization. Retrieved 11 August, 2012: http://wn.wikiopedia.org/wiki/Disability 23-1-13.

Aitchison, J, and Alidou, H. 2009. "The states and development of adult learning and education in sub-Saharan African". UNESCO http://en.wikipedia.org/wiki/Adult-education_in_Africa.

Department of Education and Science 2000. Learning for Life: White paper on Adult Education, Dublin Stationary Office: http://eric.ed.gov/PDFS/ED47120.pdf - 12/1/13.

Dickson, J. 2011. Philanthropy's Blind Spot. The Disabi Rights Movement. National Committee for Responsive Philanthropy.

Elwan, A. (199). Poverty and Disability. A review of the literature. The World Development Report. Washington D.C. World Bank. 
Gerhard, F. 2000. "Lifelong Learning more than Training" Journal of Interactive Learning Research. Vol. (11) Issue 3/4, pp.265-284. Maulau, A: Importance of Adult Education: http://www.preserve-articles.com211032647371/importance-of-adult-education-in-india.html Nyerere, J.K. (1979). "Adult Education and Development". Ninsen, Ninsen, H. and Himdsdofer, V.H. (eds) Education for Liberation and Development. The Tanzanian Experience, UNESCO Institute of Education, Hamburg and Evans Brothers Ltd. (pp-33-37).

Nzeneri, I.S. 2002. Handbook on Adult Education, Principles and Practices, Goodway Printing Press Ltd., Onitsha, Nigeria.

Poverty/Sociology: Poverty (sociology) britanica.com-retrieved 2010-10-24: http://en.wikipedia.org/wiki/poverty.

Removing Barriers to create only inclusive and accessible society for all: http://www.org/disabilities/default.asp?id=1597.

The Effects of Poverty: www.endpoverty.org/13/1/13.

The poor social problems, 1965 in http://en.wikipedia.org/wiki/poverty.

The World Bank 2010: World Bank's $\$$.25/day Poverty measure-counting the lasts criticisms. http://en.wikipedia.org/wiki/poverty \#cite_ref_wb2010a16_16-0.

The World Bank 2011. "Measuring Inequality" http://web.worldbank.org.Websites/External/Topics/Expoverty/Extpa/O.Contend. (Accessed 9-1-13.)

The World Bank 2011. Poverty and Disability. Web Accessed.http:/web.worldbank.org/Website/External/Topics/Extsocialprotection /Extdisability.

The World Bank 2012. "World Bank sees Progress against Extreme Poverty But Flags Vulnerabilities" http://www.worldbank.org len/news/2012/02/29/. (Accessed 10-1-13.

USOL: Adult Education: http:.//www.schools.utah.gov/adu;ted.

Ye, R. 2005. Disability, poverty and new development agenda. Disability, Knowledge and Research Programmes Webaccessed: http://www.dfid.gov.uk/r4d/PDF/Outputs/Disability/RedPor_agemca/pdf.

Yeo, R. 2005. Disability, Poverty and the New Development agenda: Disability, Knowledge and Research Programme. Web accessed: http://www.dfid.gov.uk/r4d/PDF/outputs/Disability/RedPor_agenda.pdf. 
